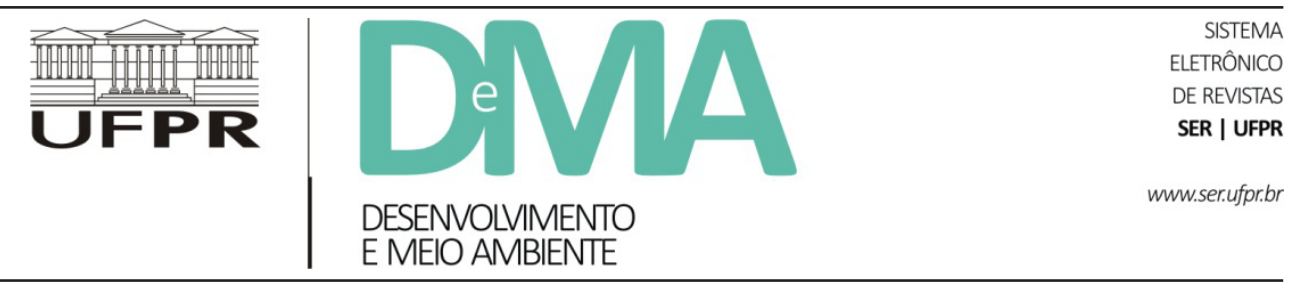

\title{
O jogo Banco Imobiliário Sustentável e os conceitos de educação para a sustentabilidade na infância
}

\section{The Game Sustainable Monopoly and Educational Concepts for Sustainability in Childhood}

\author{
Michel MENDES ${ }^{1 *}$, Neiva Senaide Petry PANOZZO ${ }^{1}$ \\ ${ }^{1}$ Programa de Pós-graduação em Educação, Universidade de Caxias do Sul (UCS), Caxias do Sul, RS, Brasil. \\ *E-mail de contato: michelbmendes@hotmail.com
}

Artigo recebido em 16 de abril de 2016, versão final aceita em 2 de dezembro de 2016.

RESUMO: A infância é compreendida como o momento do brincar, do jogar, da brincadeira, do lúdico como experiência para a formação das primeiras experiências com outras crianças, de aquisição e aprimoramento da linguagem e orientação à aquisição de comportamentos. Por isso, o objetivo deste trabalho é avaliar o jogo Banco Imobiliário Sustentável, de acordo com as três dimensões do desenvolvimento sustentável, refletindo sobre sua utilização para o público infantil na perspectiva de uma educação para a sustentabilidade. Para orientar as discussões e possibilitar o atendimento ao objetivo do presente trabalho, estruturaram-se quatro perguntas norteadoras: de acordo com as três dimensões do desenvolvimento sustentável - dimensão econômica, meio ambiente e social - estruturadas pela UNESCO, quais são contempladas pelo jogo Banco Imobiliário Sustentável e como estão abordadas?; que tipo de capitalismo pode emergir do jogo: o capitalismo industrial ou natural?; que percepção de infância subjaz ao jogo?; e é possível pensar em uma educação para a sustentabilidade a partir da proposta do jogo Banco Imobiliário Sustentável? Os resultados alcançados pela pesquisa, de natureza teórica e exploratória, revelam que as três dimensões do desenvolvimento sustentável são contempladas pelo jogo e apresentam interseções relevantes para a compreensão da complexidade que envolve a vida. No entanto, pensar em uma educação para a sustentabilidade, da maneira como o jogo está estruturado, é inviável, a menos que um profissional atue como mediador durante o jogo e possa reorganizar a estratégia basilar desse produto cultural.

Palavras-chave: jogo; infância; produto cultural; educação para a sustentabilidade.

ABSTRACT: Childhood is understood as the time of play, as an playful experience for the formation of the first experiences with other children, acquisition and improvement of language and orientation to the acquisition of behaviors. Therefore, the objective of this study is to evaluate the game Sustainable Monopoly, according to the three dimensions of sustainable development, reflecting on their use for children with a view to education for sustainability. To guide the discussions and enable the fulfillment of the objective of the present study, four guiding questions were structured: according to the three dimensions of sustainable development - dimensions 
economic, environmental and social - structured by UNESCO, which are contemplated by the game Sustainable Monopoly and how are they addressed?; what kind of capitalism can emerge from the game, industrial or natural capitalism?; what perception of childhood underlies the game?; and is it possible to think of an education for sustainability from the proposed game Sustainable Monopoly? The results achieved by the theoretical and exploratory research reveal that the three dimensions of sustainable development are included in the game and show significant intersections for understanding the complexity that involves life. However, thinking about an education for sustainability, in the way the game is structured, unless a professional acts as a mediator during the game and can reorganize the basic strategy of this cultural product.

Keywords: game; childhood; cultural products; education for sustainability.

\section{Introdução}

A infância é compreendida como o momento do brincar, do jogar, da brincadeira, do lúdico como experiência para a formação das primeiras experiências com outras crianças, de aquisição e aprimoramento da linguagem e orientação à aquisição de comportamentos. Vigotski (2003) destaca que o jogo é a primeira escola do pensamento. Sendo assim, apresenta desafios, os quais incentivam a ação do pensar. A fonte do pensamento é a linguagem, a capacidade de representar símbolos e signos. Essa capacidade de representar é o meio de comunicação criado e utilizado pelo ser humano para interagir com seu meio sociocultural.

Concordando com Vigotski, Volpato (2002) salienta que no jogo a criança "[...] aprende, verbaliza, comunica-se com pessoas que têm mais conhecimentos, internaliza novos comportamentos e, consequentemente se desenvolve" (p. 49). É nesse sentido que o jogo proporciona às crianças um meio de enriquecer suas experiências e provocá-las a crescer de maneira integral.

Vigotski (2003) destaca que o jogo "[...] é uma experiência social viva e coletiva da criança e, nesse sentido, constitui um instrumento insubstituível para educar os hábitos e aptidões sociais" (p. 106). Para Elkonin (2009), o jogo possui características que o situam como um protótipo da futura atividade séria.
Assim, o jogo de tabuleiro Banco Imobiliário Sustentável configura-se como um produto cultural destinado à infância, uma vez que seu público-alvo são crianças a partir dos seis anos de idade, situando a discussão do desenvolvimento sustentável como mola para uma possível conscientização sobre a temática.

O trabalho é de natureza teórica e exploratória, que busca explorar seu objeto de pesquisa, o jogo Banco Imobiliário Sustentável, por meio das discussões propostas e aprofundar os conhecimentos na área.

Diante do exposto, o objetivo deste trabalho é avaliar o jogo Banco Imobiliário Sustentável de acordo com as três dimensões do desenvolvimento sustentável, refletindo sobre sua utilização para o público infantil na perspectiva de uma educação para a sustentabilidade. Para responder ao objetivo do trabalho, estruturaram-se quatro perguntas norteadoras, a saber: de acordo com as três dimensões do desenvolvimento sustentável - econômica, meio ambiente e social - estruturadas pela UNESCO, quais são contempladas pelo jogo Banco Imobiliário Sustentável e como estão abordadas?; que tipo de capitalismo pode emergir do jogo: o capitalismo industrial ou natural?; que percepção de infância subjaz ao jogo?; e é possível pensar em uma educação para a sustentabilidade a partir da proposta do jogo Banco Imobiliário Sustentável? 
Essas questões atuam como uma bússola para a organização reflexiva do trabalho. Pelos inúmeros olhares lançados sobre o jogo, a partir dessas questões norteadoras, a ideia não é aprofundar suas discussões, mas sim problematizar possíveis inquietações.

Dessa forma, para que as perguntas possam ser discutidas, o presente artigo encontra-se organizado em quatro seções, além da introdução e da conclusão. Na primeira seção - A infância e o uso de jogos - o objetivo é situar a relevância do uso de jogos na infância como primeira escola do pensamento. Na segunda - O jogo Banco Imobiliário Sustentável - o objetivo é apresentar o jogo e descrever sua utilização. Na terceira - Educação, desenvolvimento sustentável e sustentabilidade - o objetivo é apresentar as três dimensões do desenvolvimento sustentável, considerações sobre sustentabilidade e desenvolvimento sustentável, capitalismo natural e educação para a sustentabilidade. Na última seção - O Banco Imobiliário Sustentável e seus diálogos com as dimensões do desenvolvimento sustentável, com o capitalismo, com a infância e com a educação para a sustentabilidade - o objetivo é articular o jogo com essas variáveis e situar sua relevância para a infância.

\section{A infância e o uso de jogos}

A infância é um dos momentos de maior utilização de jogos, pois nesse período a ocupação por atividades lúdicas e educativas assume o caráter de formação das primeiras experiências com outras crianças, de aquisição e aprimoramento da linguagem e orientação à aquisição de comportamentos. De acordo com Vigotski (2003), o jogo é a primeira escola de pensamento, pois possui desafios e estes demandam o exercício do pensar.
A fonte do pensamento é a linguagem (Vigotski, 2007). O autor afirma que ela surge como meio de comunicação entre as crianças e o meio sociocultural, sendo aos poucos convertida em pensamento interno. É nesse sentido que o jogo proporciona às crianças um meio de enriquecer suas experiências e provocá-las a crescer de maneira integral.

Fernández (2001) considera que "o pensar é como um barco: se ancorado no desejar, é movido pelos ventos da crua realidade, premido pela dor da perda, pela raiva das tempestades e pelas brisas da solidariedade com o sofrimento alheio" (p. 109). Assim, o jogo atua em um campo vivo em que as regras e as decisões se encontram em constante transformação e adaptação para suas realidades e necessidades, o que demanda o querer participar, pelo jogador, e enfrentar um possível mar com ventos ou não, sabendo que após a tempestade vem a calmaria, ou seja, o turbilhão do pensar é convertido em reflexão pelas atividades contidas no jogo. Ainda, a autora afirma que "a autoria do pensamento supõe diferenciação, agressividade saudável, 'revolta íntima', a partir da qual há a possibilidade de reencontro com o outro. Acesso a nós mesmos" (Fernández, 2001, p. 105).

Dessa forma, o jogo, conforme Huizinga (2000) destaca, é uma atividade voluntária, realizada em determinado espaço e tempo, composto de regras e com uma finalidade, acompanhado por sentimentos de alegria, tensão e consciência de que sua realização é uma ilusão da vida real. Para o estudioso, o jogo faz parte da cultura humana. No entanto, é anterior ao homem, uma vez que os animais já brincavam e jogavam uns com os outros.

O que difere o jogo humano daquele dos animais é a utilização de uma capacidade puramente humana, a linguagem. Esta, segundo Huizinga (2000), “[...] é o primeiro e supremo instrumento 
que o homem forjou a fim de poder comunicar, ensinar e comandar" (p. 7).

Para Leiff \& Brunelle (1978), o jogo e a linguagem possuem uma ligação entre si, um parentesco, tal que: “[...] ambos representam a realidade, ambos a transpõem, ambos são a sua ficção" (p. 59). A ficção, talvez, seja uma das características mais marcantes do uso de jogos pelas crianças, pois, com o desenvolvimento psíquico, a estruturação da linguagem e do pensamento e a capacidade de imaginar e projetar situações fictícias se ampliam. Como em todo pensamento ou situação imaginária, as regras fazem parte de sua estrutura, delimitando as possibilidades e alcances da linguagem a ser utilizada.

O emprego de jogos na infância é um recurso multiformador, pois, conforme Ferran et al. (1979), apresentam funções constitutivas, como: a ficção, que favorece a criatividade de inventar e se deslocar do mundo real para o irreal; o descanso, que auxilia o afastamento das tensões e pressões do dia a dia; a exploração, que incentiva o poder de explorar novos mundos e suas especificidades; a socialização, que oferece a possibilidade de entrar em contato e construir relações com outras crianças ou participantes do jogo; a competição, que favorece, desde que de maneira saudável, a busca pela superação de um desafio; e a regra, que é a função principal de qualquer jogo, pois ela determina os caminhos a serem percorridos pelos jogadores e afeta diretamente as funções descritas anteriormente, uma vez que constitui uma condição sine qua non.

De acordo com o apresentado, o jogo é um recurso que favorece o desenvolvimento da linguagem e do pensamento, os quais, por sua vez, estão intimamente ligados à socialização. Vigotski (2003) destaca que o jogo "[...] é uma experiência social viva e coletiva da criança e, nesse sentido, constitui um instrumento insubstituível para educar os hábitos e aptidões sociais" (p. 106).

No jogo a criança toma consciência de si mesma, aprende a desejar e a subordinar a seu desejo os impulsos afetivos passageiros, aprende a atuar submetendo suas ações a um determinado modelo, a uma norma de comportamento. Volpato (2002) afirma que, "pelo jogo, a criança aprende, verbaliza, comunica-se com pessoas que têm mais conhecimentos, internaliza novos comportamentos e, consequentemente, se desenvolve" (p. 49).

Nesse contexto, a aquisição de novas informações e de novos comportamentos pelo jogo está em consonância com o apresentado por Elkonin (2009), quando situa o jogo como um protótipo da futura atividade séria, isto é, as novas experiências proporcionadas pelo jogo e pelas interações orientam para a consciência de um comportamento futuro.

Com isso, a utilização de jogos para a infância evidencia a necessidade de diferenciação dos recursos, conforme o período de vida, uma vez que visam estimular e desenvolver determinadas competências e comportamentos. Isso significa que existem diferenças entre instrumentos voltados para cada período do desenvolvimento humano. Para Postman (1999, p. 86), com o avanço tecnológico, essa relação se rompeu, havendo a padronização de informações, sem diferenciação entre o que é do universo adulto e o que é do infantil, ao salientar que:

a infância [...] foi o fruto de um ambiente em que uma forma especial de informação, exclusivamente controlada por adultos, tornou-se pouco a pouco disponível para as crianças por meios considerados psicologicamente assimiláveis. A subsistência da infância dependia dos princípios da informação controlada e da aprendizagem sequencial. Mas o telégrafo iniciou o processo de extorquir do lar e da escola o controle da informação. Alterou o tipo de informação 
a que as crianças podiam ter acesso, sua qualidade e quantidade, sua sequência, e as circunstâncias em que seria vivenciada.

Postman (1999) reforça o papel da mídia em fornecer a todos o mesmo tipo de informação, cujo processo iniciou com o telégrafo, seguido pelo rádio, pela televisão e atualmente pela internet, um poderoso meio de padronizar simultaneamente o acesso à informação. Com o surgimento do ambiente midiático e do consumismo, os produtos culturais para a infância proliferam, os segredos tornam-se não segredos, visíveis a qualquer público e a qualquer hora. Logo, "sem segredos, evidentemente, não pode haver uma coisa como a infância" (Postman, 1999, p. 94).

Assim, uma das finalidades que movem o trabalho é identificar a percepção de infância contida no produto cultural Banco Imobiliário Sustentável, sob orientação da ideia de fim da infância, conforme a breve contextualização realizada anteriormente, embasada em Postman (1999).

O produto cultural, como resultado de uma construção social, reflete o momento em que a sociedade está inserida, atribuindo à sua construção características que estejam atreladas a esse momento. O jogo em questão situa uma fase em que a sociedade tenta, até determinado ponto, adaptar o sistema de crescimento econômico a um crescimento com redução de impactos ambientais e com maior reutilização dos recursos extraídos da natureza ou transformados em produtos secundários.

Nos primeiros modelos do jogo Banco Imobiliário, as discussões eram outras e com temas diferentes, resultado do momento em que a sociedade vivia na década de 1930. Aos poucos, o jogo foi se adaptando às demandas de consumo e de mídia, tornando-se um produto das culturas de moda.

No entanto, o tema inserido na versão do jogo em foco neste trabalho não poderá ser apenas resultado de uma cultura de moda, pois envolve a manutenção da vida na Terra, a sustentação da relação entre o homem e a natureza. Por isso, espera-se que o jogo Banco Imobiliário Sustentável seja um produto de uma cultura que venha para ficar e ressignificar suas relações, possibilitando novas alternativas de aliar desenvolvimento e conservação.

Porém, para que o jogo possa buscar novas maneiras de conceber o mundo e sua ligação entre ser humano e natureza, os modos de operar essa relação, é preciso que sua base estrutural seja alterada, pois uma nova cultura, isto é, um novo modo de ver e se portar com o planeta passa anteriormente por uma reestruturação na maneira como o homem percebe a natureza e seus pertencentes. Ao longo do artigo será retomada essa discussão.

A seguir, apresenta-se o objeto de análise deste trabalho.

\section{O jogo Banco Imobiliário Sustentável}

O jogo de tabuleiro Banco Imobiliário Sustentável foi lançado no Brasil em 2008, resultado da parceria entre as empresas brasileiras Estrela ${ }^{1}$ e Braskem $^{2}$, configurando-se como o primeiro brinquedo produzido com polietileno verde de matéria-prima $100 \%$ renovável.

O Banco Imobiliário Sustentável é resultado do jogo original Monopoly, criado nos Estados Unidos por Charles Darrow, em 1935, com o in-

\footnotetext{
1 Foi criada em 1937, em São Paulo. Na década de 1940, lançou inúmeros brinquedos, dentre eles o Banco Imobiliário (Estrela, 2015).

2 Foi criada em 2002, pela integração de seis empresas da Organização Odebrecht e do Grupo Mariani (Braskem, 2015).
} 
tuito de ensinar a teoria da economia (Wikipédia, 2015). No entanto, para Fleury e Somain (2009), o jogo surgiu no momento em que os Estados Unidos enfrentavam a crise de 1929 e teria sido inventado pelos irmãos Parker, com o intuito de conseguir dinheiro para alimentar sua família, em Atlantic City, também em 1935.

Segundo Fleury \& Somain (2009), os primeiros modelos do jogo retratavam as ruas da cidade de origem do jogo, Atlantic City, e permaneceram por muitos anos nesse formato, inclusive quando comercializados em outros países. O circuito tradicional do Monopoly era retratar as principais ruas da capital do país, tornando-se milionário e detentor desses espaços.

No entanto, com a expansão do jogo, foram acrescidas as ruas e avenidas principais de cada país, e não mais apenas da capital (Fleury \& Somain, 2009). O que não mudou ao longo dos tempos e das novas edições foi o caráter capitalista e a busca pela maior fortuna.

Atualmente, a empresa Hasbro detém os direitos autorais do jogo, sendo a terceira maior empresa de brinquedos e jogos do mundo e editora do jogo de tabuleiro mais vendido da história, o Monopoly. Ainda, conforme Fleury \& Somain (2009), o jogo ganhou tamanha proporção que já é comercializado em mais de 80 países e encontra-se traduzido para mais de 30 línguas. No Brasil, o Monopoly é traduzido e vendido como Banco Imobiliário pela empresa Estrela.

Por ser um jogo de tabuleiro, o Banco Imobiliário está estruturado dentro de um circuito, no qual o objetivo é comprar, vender ou alugar imóveis, instituições, ações, ruas e avenidas, tornando-se o maior milionário entre os participantes e fugindo da falência. Ao longo do tempo, o jogo foi se adaptando às mudanças, ao consumismo e às demandas midiáticas, principalmente aos filmes e desenhos infantis, inserindo características específicas para determinados grupos, conforme se pode observar na Figura 1, que apresenta as embalagens de alguns jogos Banco Imobiliário em circulação no mercado.

Os primeiros jogos Banco Imobiliário vendidos no Brasil voltavam-se para o público infantil, sem distinção entre gêneros, abordando as principais ruas, avenidas e prédios dos estados de São Paulo e Rio de Janeiro. Com o desenvolvimento das produções cinematográficas e o aprimoramento das técnicas de publicidade e propaganda, as crianças se tornam o alvo secundário do cinema, pois, com base nos personagens que fazem sucesso em suas telas, são produzidos brinquedos que remetem a eles ou que simplesmente os copiam. No caso do Banco Imobiliário, essa tática também foi inserida em sua estrutura, conforme evidenciam as imagens da Figura 1, nas quais a estratégia empregada é atingir diretamente as crianças, tornando-as consumidoras desses produtos culturais.

A inserção de filmes, desenhos animados, histórias em quadrinhos, eventos e esportes na estrutura do Banco Imobiliário afastou o tradicional modelo de circuito entre São Paulo e Rio de Janeiro para dar espaço a mansões e arranha-céus, na versão Luxo; pontos turísticos da cidade olímpica do Rio de Janeiro, na versão Cidade Olímpica; castelos e demais especialidades do universo das princesas Disney, na versão Princesas; maior facilidade e rapidez na construção e compra de casas, na versão Júnior; espaços do Brasil escolhidos pela população por meio de votação na internet, na versão Brasil; e castelos, florestas e casas dos personagens do filme Shrek, na versão Shrek. Nas demais versões ocorrem as mesmas alterações das casas, com o objetivo de inserir os traços do novo produto no jogo. Uma das características que chamam a atenção, em algumas versões do jogo, é a presença de uma máquina de cartão de créditos, um objeto distante 


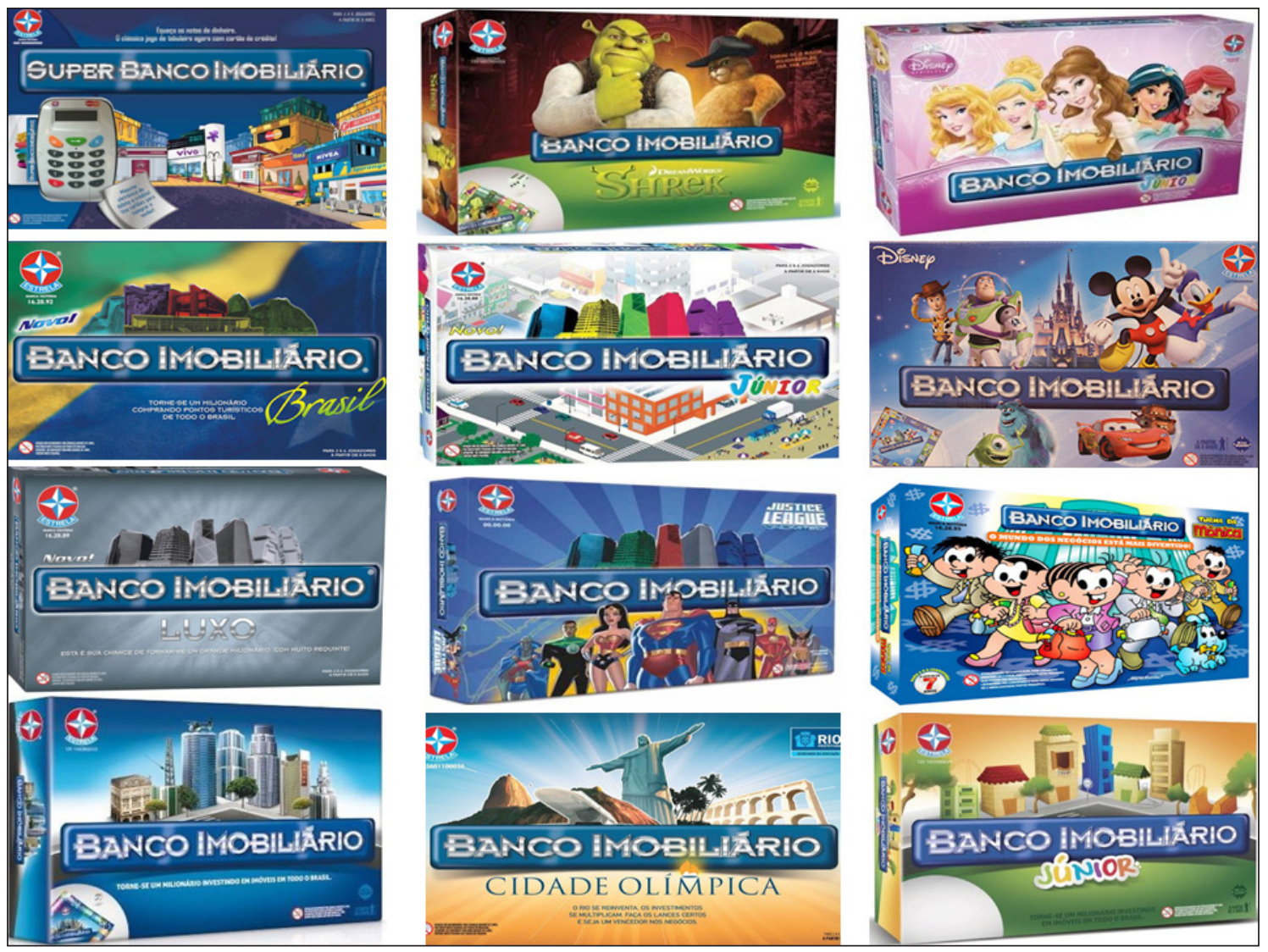

FIGURA 1 - Jogos Banco Imobiliário clássicos e temáticos.

FONTES: Elaborada pelos autores a partir de imagens do site da Estrela.

do universo infantil, considerando-se que o público-alvo são crianças a partir dos seis anos de idade.

Observa-se, além desses aspectos relacionados à diferenciação de espaços e artefatos culturais, que algumas versões apresentam o foco em determinado gênero, como ocorre no Banco Imobiliário Princesas, voltado ao público feminino, o que não impossibilita sua utilização pelo gênero masculino.

A alta inserção das animações infantis e criações destinadas a esse público é perceptível nos jogos Banco Imobiliário, o que direciona e situa a infância como um momento de alta rotatividade e consagração de personagens e das crianças como indivíduos potencialmente consumidores. "O pacto com a imagem exige pedagogia do consumo" (Lemos, 2007, p. 51). Essa denominação de "pedagogia do consumo" é entendida pela autora como o processo de venda do imaginário, da ilusão de completude a que estão expostos as crianças e os jovens, sem que com isso excluam-se os adultos. "O mundo infantil tornou-se um grande mercado. Todos querem vender, para as crianças, desde festas infantis com buffets sofisticados a modelitos coquetes, levando a menina a se 'produzir' desde cedo" (p. 50). 
Nesse contexto de mudança e adaptações é que surge o Banco Imobiliário Sustentável, o qual tem por objetivo o aspecto educacional, e não o econômico. Visa à conscientização sobre a sustentabilidade. A preocupação do jogador é com o meio ambiente, sendo que o que importa é um mundo mais consciente.

No Banco Imobiliário Sustentável, não apenas a estética da caixa mudou - como habitualmente ocorre em relançamentos de produtos -, mas também o modo de produzir os materiais que compõem o jogo, o significado atribuído às cartas dinheiro e sua dinâmica: o dinheiro foi substituído por certificados de carbono; imóveis, ruas e instituições agora são reservas naturais, regiões produtoras de cana-de-açúcar ${ }^{3}$ e companhias; os peões, as casas e as pousadas são feitos de plástico verde, enquanto as cartas e a caixa são de papel reciclável, conforme Figura 2. O novo Banco Imobiliário Sustentável traz todo o dinamismo do mundo dos negócios aliado à sustentabilidade para os dias de hoje: novos terrenos e novas oportunidades, com valores mais próximos da realidade.

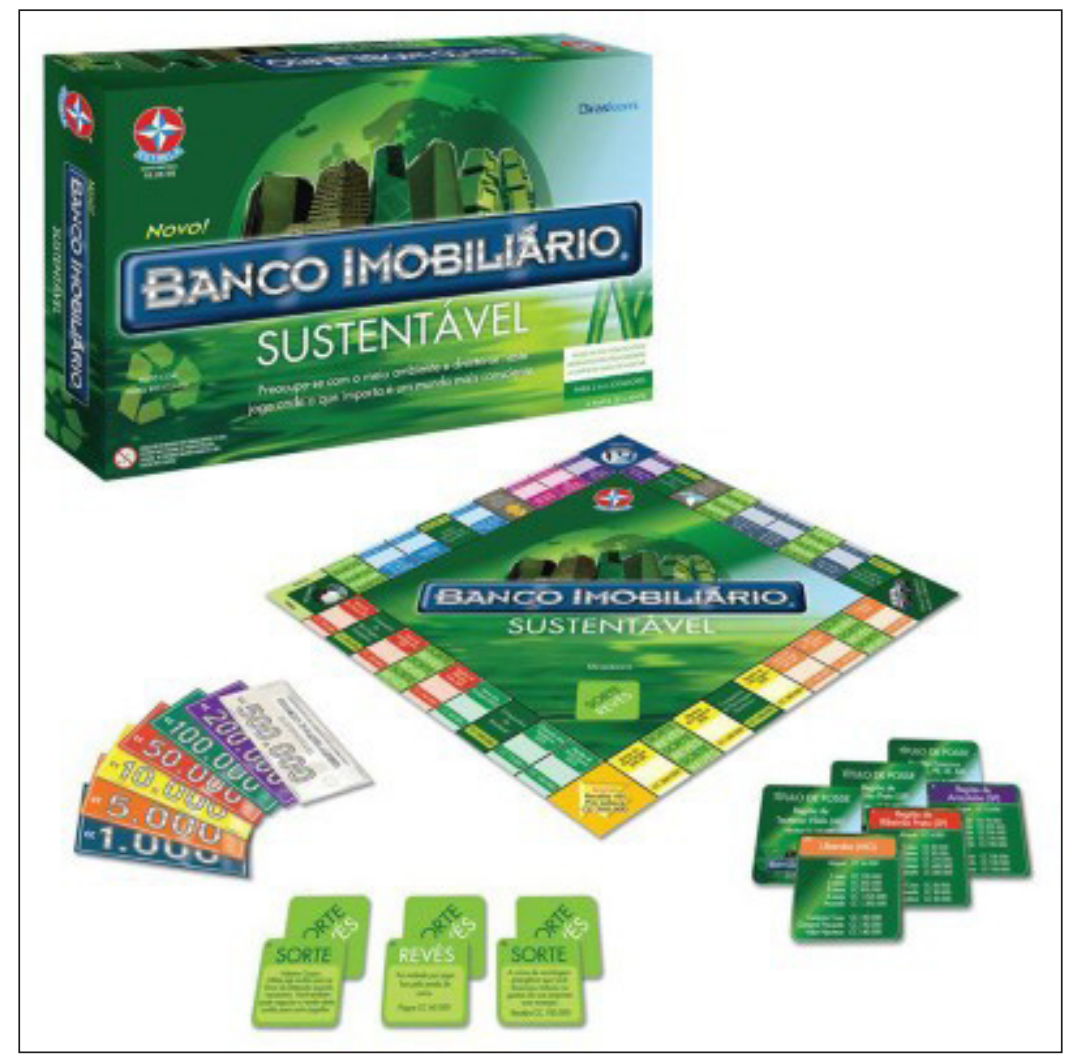

FIGURA 2 - Banco Imobiliário Sustentável.

FONTE: <https://ecografismo.wordpress.com/2013/02/20/banco-imobiliario-sustentavel/>.

3 O enfoque sobre as regiões produtoras de cana-de-açúcar justifica-se por ser essa a matéria-prima utilizada, pela Braskem, para a produção do polietileno verde e, consequentemente, de algumas peças do jogo. 
As cartas de título de posse representam a possibilidade de compra de uma propriedade, de uma região produtora de cana-de-açúcar ou de uma companhia verde, já que o objetivo é ganhar o máximo de certificados de carbono, e esses títulos possibilitam sua arrecadação ao longo do jogo. As regiões e reservas naturais ali contempladas permeiam nove estados do Brasil: Alagoas, Bahia, Goiás, Mato Grosso do Sul, Minas Gerais, Pernambuco, Rio de Janeiro, São Paulo e Sergipe.

A outra oportunidade de enriquecer com certificados de carbono é pela compra dos títulos de posse de companhia, com as seguintes opções: Companhia de Reciclagem Energética, Companhia de Agricultura Orgânica, Companhia de Reciclagem Mecânica, Companhia de Reflorestamento, Companhia de Biodiesel e Companhia de Energia Eólica. Todas essas possibilidades de se tornar milionário incentivam e apelam para a necessidade de possuir mais bens e mais cartas de posse e certificados de carbono, implicando a queda do outro participante, uma vez que a maior fortuna é alcançada quando o participante possuir maior domínio sobre as propriedades e sobre os participantes do jogo.

Portanto, há um estímulo à competição e ao alcance da vitória do mais bem-sucedido financeiramente. $\mathrm{O}$ jogo apresenta fácil compreensão de suas regras, segundo as quais os jogadores iniciam a competição com um determinado valor em certificados de carbono e vão lançando os dados, o que resulta no deslocamento dos participantes pelo tabuleiro, na tomada de decisão sobre os obstáculos (movidos pelas cartas sorte e revés) e em possibilidades de se iniciar no ramo do investimento por meio da compra de companhias, propriedades e regiões produtoras de cana-de-açúcar.

Porém, as informações do jogo Banco Imobiliário Sustentável que foram avaliadas neste trabalho são aquelas contidas nas cartas sorte e revés, as quais serão descritas e analisadas na seção 5, momento em que serão cruzadas com as dimensões da sustentabilidade, apresentadas na próxima seção.

\section{Educação, desenvolvimento sustentável e sustentabilidade}

A sustentabilidade é um dos termos mais utilizados atualmente, tornando-se um jargão político, em muitos casos. A ideia contida no termo difere fortemente das relações simplistas de economia de água ou utilização de fontes renováveis; vai além dessas ações. "Sustentabilidade consiste num conceito, a bem da verdade, bastante amplo e admite variações de acordo com interesses e posicionamentos. Além do que, ainda é recente e por isso mesmo sujeito a ambiguidades e dilemas quanto ao seu uso e significado" (Ruscheinsky, 2003, p. 41).

Devido à alta exploração dos recursos naturais, a sustentabilidade tem se tornado uma utopia, a qual demanda equilíbrio entre os setores econômico, social e ambiental.

\begin{abstract}
A sustentabilidade implica em equilíbrio entre a tendência para a morte entrópica do planeta, gerada pela racionalidade do crescimento econômico, e a construção de uma produtividade neguentrópica baseada no processo fotossintético, na organização da vida e na criatividade humana. A sustentabilidade é a marca da proibição na ordem econômica (Leff, 2010, p. 210, grifo do autor).
\end{abstract}

Pensar em sustentabilidade significa, antes disso, pensar em desenvolvimento sustentável. Loureiro (2012, p. 55) afirma que, para muitos autores, desenvolvimento sustentável nem é um conceito, mas sim 
[...] uma "ideia-força", um conjunto de princípios manifestos em busca de um desenvolvimento qualificado por uma preocupação, qual seja: crescer sem comprometer a capacidade de suporte dos ecossistemas e seus ciclos, garantindo a existência social e de outras espécies em longo prazo.

De acordo com o "Relatório de Brundtland: nosso futuro comum", elaborado pela Comissão Mundial sobre Meio Ambiente e Desenvolvimento (CMMAD) (1991), “o desenvolvimento sustentável é aquele que atende às necessidades do presente sem comprometer a possibilidade de as gerações futuras atenderem a suas próprias necessidades" ( $\mathrm{p}$. 46). Os dois termos-chave que compõem o conceito de desenvolvimento sustentável (DS) são: necessidade e estágio da tecnologia e da organização social. No primeiro, a ideia que deriva do termo é de atendimento às necessidades básicas da vida, e isso demanda possibilidade, ou seja, reavaliar o atual sistema para garantir o acesso às necessidades de maneira equitativa, ${ }^{4}$ principalmente pela parcela mais pobre da população. No segundo, a ideia contida no termo reflete uma reestruturação dos processos de extração de recursos para o avanço tecnológico e da organização social.

Salienta-se ainda que o desenvolvimento sustentável é

[...] um processo de transformação no qual a exploração dos recursos, a direção dos investimentos, a orientação do desenvolvimento tecnológico e a mudança institucional se harmonizam e reforçam o potencial presente e futuro, a fim de atender às necessidades e aspirações humanas (CMMAD, 1991, p. 49).

Leff (1998) amplia a definição construída pela CMMAD ao inserir de maneira acentuada o papel político e participativo da população nesse processo. Para o autor, o desenvolvimento sustentável é um projeto social e político que

[...] apunta hacia el ordenamento ecológico y la descentralización territorial de la producción, así como a la diversificación de lós estilos de desarrollo y lós modos de vida de las poblaciones que habitan el planeta. Em este sentido, oferece nuevos princípios a lós procesos de democratización de la sociedad, que inducen la participación directa de las comunidades em la apropiación y transformación de sus recursos ambientales (Leff, 1998, p. 50).

A partir da estruturação de um desenvolvimento sustentável é que surge a ideia de sustentabilidade, pois esse conceito está atrelado ao sentido de equilíbrio entre os campos econômico, social e ambiental, o que demanda tempo e transformação nas matrizes comportamentais do atual desenvolvimento. Para Dias (2015), "sustentabilidade pode ser definida como o destino pretendido do desenvolvimento sustentável e deve ser considerada um alvo em movimento, uma linha no horizonte" (p. 44).

Para Jacobi (1999), pensar em sustentabilidade implica compreender a necessária inter-relação entre o equilíbrio ambiental, a justiça social, a qualidade de vida e o rompimento com o atual sistema de desenvolvimento. Ruscheinsky (2003, p. 43) amplia o debate ao situá-lo como "[...] a capacidade de um modelo ou sistema sustentar-se na dinâmica evolutiva sem permitir que algum setor aprofunde-se em crises de tal forma que venha a atingir a totalidade".

Por essa linha de sentidos é que a UNESCO (2005) estruturou as três dimensões ou, mais comumente, os três pilares do desenvolvimento sustentável: o meio ambiente, a economia e a sociedade, conforme Figura 3.

\footnotetext{
4 A promoção de equidade apresentada avança a barreira do aqui e do agora para projetar a equidade do presente para o futuro, de nação para nação.
} 
De acordo com a UNESCO (2005), a dimensão do meio ambiente, também chamada de ambiental, é aquela que busca a conscientização do meio ambiente e de sua fragilidade em relação às ações antrópicas, do compromisso com uma adequada gestão e proteção ambiental, garantindo-lhe sua integridade. A dimensão econômica está atrelada à ideia de limites, de seu conhecimento, das possibilidades que o meio ambiente oferece e do uso dessa fonte. A ideia, nessa dimensão, permeia a vitalidade do sistema econômico. Já a dimensão social envolve a consciência do papel do cidadão diante das transformações possíveis de ser realizadas, incentivando o uso democrático para o fortalecimento das comunidades, garantindo-lhes equidade de valores e condições.

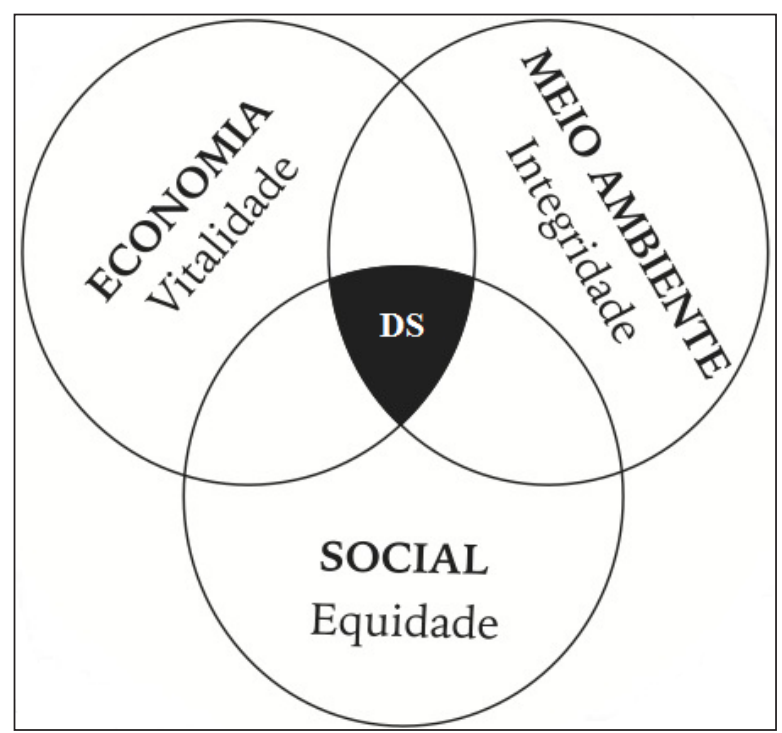

FIGURA 3 - Dimensões do desenvolvimento sustentável. FONTE: Adaptada de Dias (2015).

Na Figura 3, pode-se observar que o DS é resultado da união entre as três dimensões, as quais realizam movimentos de interseção, o que permite o equilíbrio entre essas dimensões. A estruturação de um DS pode levar à projeção de uma vida sustentável, mesmo que isso pareça uma utopia.

\begin{abstract}
A sustentabilidade parece conter ou contemplar um movimento social histórico, se um elemento agregador e mediador, portador de um projeto de mudança universalizante, com fôlego para articular setores sociais díspares provenientes de movimentos sociais, de agências estatais, do mundo acadêmico e das ONGs. A identidade que parece integrar esta multiplicidade seria a orientação para o desenvolvimento de uma sociedade sem desigualdades sociais ou uma sociedade sustentável (Ruscheinsky, 2003, p. 43).
\end{abstract}

Para que a efetivação das três dimensões ocorra, deve-se considerar o contexto cultural e político de cada região, uma vez que as mudanças envolvem, inicialmente, a educação, e essa está intimamente ligada à dimensão cultural. Segundo o diretor-geral da UNESCO, em 1999, Federico Mayor,

\begin{abstract}
a chave do desenvolvimento sustentável e autônomo é a educação; uma educação que alcance todos os membros da sociedade, em novas modalidades e por intermédio de novas tecnologias para proporcionar a todos verdadeiras oportunidades de aprender ao longo da vida [...] a fim de promover atitudes e condutas propícias à cultura da sustentabilidade (UNESCO, 1999, prefácio).
\end{abstract}

A educação para a sustentabilidade é um dos caminhos apontados pela UNESCO (1999) para um futuro possível, na busca de um desenvolvimento socialmente equitável, economicamente exequível e ambientalmente possível. A educação oferece uma interpretação crítica do mundo, principalmente no que tange às questões de deficiências e injustiças, fazendo com que haja uma maior sensibilização e conscientização, incentivando a busca por melhorias e inovações que favoreçam essas questões. Ou seja, "a educação é, em síntese, a melhor esperança e o meio 
mais eficaz que a humanidade tem para alcançar o desenvolvimento sustentável" (UNESCO, 1999, p. 35).

Em consonância com o exposto acima, Loureiro (2012) considera que a educação é uma das estratégias basilares desse modelo de desenvolvimento, embora seja pouco valorizada, pouco discutida. No entanto,

se reconhecermos que não há transformação social sem educação (que sozinha não faz "milagres" nem é a salvação), qualificá-la no sentido da apreensão de premissas que garantem a reflexão sobre as questões postas pela ecologia política, e que são afetas à sustentabilidade, é evidentemente algo pertinente e necessário diante dos desafios contemporâneos (Loureiro, 2012, p. 75).

Nesse sentido, Freire (1981) destaca que a educação só é educação quando possui esperança: esperança em mudar, em transformar as realidades. Afinal, o homem é um ser de relações, ele está no mundo e com o mundo. Estando com o mundo e por ser um ser inconcluso, o homem, e seu ímpeto em transformar o mundo ao seu redor, cria culturas (Freire, 1981).

Ademais, o homem, por ser um ser de relações, cria relações de reflexão, de consequência, de transcendência e de tempo. São essas características que delimitam a transformação do mundo em cultura, a marcação histórica do ser humano, pois a cultura criada não é repetida, e sim recriada, ou, então, criam-se novas culturas. "O homem pode fazê-lo porque tem uma consciência capaz de captar o mundo e transformá-lo" (Freire, 1981, p. 31).

Freire (1981, p. 32-33) ressalta que com a educação deve ser a mesma coisa: deve-se deixar que os estudantes criem e inventem por conta própria, afinal, essa é uma característica inata ao ser humano:

caso contrário domesticamos, o que significa a negação da educação. Um educador que restringe os educandos a um plano pessoal impede-os de criar. Muitos acham que o aluno deve repetir o que o professor diz na classe. Isso significa tomar o sujeito como instrumento. O desenvolvimento de uma consciência crítica que permite ao homem transformar a realidade se faz cada vez mais urgente.

A educação como a chave para a mudança é uma ideia defendida tanto pela UNESCO (1999) como por Freire (1981). E por onde começar essa mudança? Existe um ponto demarcado? Acredita-se que não, embora haja consciência sobre os primeiros caminhos a serem percorridos. Em vista disso, Freire (1981, p. 33) salienta que:

não há transição que não implique um ponto de partida, um processo e um ponto de chegada. Todo amanhã se cria num ontem, através de um hoje. De modo que o nosso futuro baseia-se no passado e se corporifica no presente. Temos de saber o que fomos e o que somos, para saber o que seremos.

Procurar saber o que cada um é, o que foi e o que será é uma tarefa árdua, pois implica avaliar a si mesmo, seus atos, suas consequências, sua postura diante dos outros e com os outros. Dessa forma, "quando o homem compreende sua realidade, pode levantar hipóteses sobre o desafio dessa realidade e procurar soluções. Assim, pode transformá-la e com seu trabalho pode criar um mundo próprio: seu eu e suas circunstâncias" (Freire, 1981, p. 30).

Nessa mesma linha de pensamento, ao discutir o desenvolvimento sustentável e a sustentabilidade planetária, é necessário pensar em que tipo de capitalismo a sociedade mundial irá se ancorar. $\mathrm{O}$ que está posto na "mesa" das economias mundiais é que o atual sistema capitalista não coincide com os ideais do DS e da sustentabilidade. De acordo com Hawken et al. (2007, p. 4), "o capitalismo, tal que vem sendo praticado, é uma aberração lucrativa e insustentável do desenvolvimento humano". 
Hawken et al. (2007) propõem a transição do capitalismo industrial para o natural, embasada por quatro estratégias. Na primeira, produtividade radical dos recursos, a ideia é ampliar o aproveitamento dos recursos naturais extraídos, proporcionando mais tempo de vida e manutenção da estrutura ecossistêmica, redução da poluição e maior possibilidade de empregos. $\mathrm{Na}$ segunda, o biomimetismo alia-se fortemente à primeira estratégia, em que a ideia de desperdício deve ser abolida para viabilizar a reutilização de todos os tipos de resíduos e, assim, eliminar o lançamento de substâncias tóxicas no meio ambiente. Na terceira, uma economia de serviço e de fluxo direciona-se para a ressignificação de valores entre o produtor e o consumidor, em que a economia transforme a ideia de aquisição de bens de maneira impulsiva e desnecessária para uma relação de necessidade e manutenção da melhoria na qualidade de vida. $\mathrm{Na}$ última estratégia, investimento no capital natural, a preocupação é com a manutenção da vida na Terra, com o equilíbrio sistêmico do ambiente natural, com proporcionar condições de reestruturação e sustentação desse ambiente e ampliar as áreas de potencial para extração humana. Implementando-se as três estratégias iniciais, já se está realizando a manutenção da última estratégia, o que evidencia um olhar sistêmico sobre um futuro e urgente capitalismo.

A trajetória da sociedade capitalista e da engrenagem econômica por ela ensejada tem sido apontada como ecologicamente insustentável no sentido de que os sinais de degradação do capital natural e a deterioração de seus fluxos de serviços tornam-se cada vez mais claros. Entre outros, pode-se citar a recorrência de desastres ecológicos, as mudanças no clima e a contínua perda de diversidade biológica representada pela homogeneização de paisagens naturais e pela escalada da perda irrecuperável de espécies e de seus habitats. A ocorrência da mais recente crise econômica representa, em última instância, a inadequação de um modelo socioeconômico-ecológico construído sobre as premissas do capitalismo de livre-mercado e do crescimento econômico ilimitado incapaz de promover o bem-estar sustentável da sociedade humana e garantir os mesmos padrões para as gerações futuras (Andrade et al., 2012, p. 715).

Conforme o jogo Banco Imobiliário Sustentável, a conscientização sobre a sustentabilidade é seu foco principal. No entanto, inserir as discussões ambientais ou a ludicidade ambiental em um jogo para o público infantil demanda articulação entre o objetivo do jogo e suas variáveis. No Banco Imobiliário Sustentável, a sustentabilidade é abordada de maneira competitiva e apoiada pelo viés econômico, o que impera no atual sistema econômico criado pelo ser humano.

Portanto, para que o jogo possa ser avaliado e seus objetivos e finalidades sejam alcançados, algumas perguntas norteiam a avaliação: quais são as dimensões do desenvolvimento sustentável implícitas no jogo Banco Imobiliário Sustentável?; que tipo de capitalismo pode emergir no jogo?; é possível pensar em uma educação para a sustentabilidade, a partir da estrutura proposta?; e que percepção de infância subjaz ao jogo Banco Imobiliário Sustentável? A avaliação e as reflexões sobre esses questionamentos encontram-se na próxima seção.

\section{O Banco Imobiliário Sustentável e seus diálogos com as dimensões do desenvolvimento sustentável, com o capitalismo, com a infância e com a educação para a sustentabilidade}

Diante do objetivo deste trabalho, isto é, avaliar o jogo Banco Imobiliário Sustentável de 
acordo com as três dimensões do desenvolvimento sustentável, refletindo sobre sua utilização para o público infantil na perspectiva de uma educação para a sustentabilidade e do referencial teórico contido nas três seções, buscou-se responder ao objetivo e atender às suas finalidades nesta seção, por meio do cruzamento de informações entre as cartas sorte e revés e as dimensões do DS e do desenvolvimento insustentável (DI).

Para a análise das cartas sorte e revés, utilizaram-se as três dimensões do DS e critérios criados para auxiliar na determinação dessas dimensões. A proposta das cartas sorte é apresentar ações positivas para o DS, ao passo que, nas cartas revés, constam ações negativas. Por isso, os critérios que situam as dimensões do DS também foram utilizados para identificar o DI, o qual evidencia propos- tas no sentido contrário do sustentável, conforme quadros abaixo, respectivamente.

Dessa forma, a análise das descrições contidas nas cartas sorte e revés revela um panorama de equilíbrio entre as três dimensões do DS e do DI, conforme evidenciam as Tabelas 3 e 4. Ressalta-se que as três dimensões possuem diversos pontos de intercruzamento, comportando-se de maneira interdependente. No entanto, buscou-se organizá-las conforme os critérios acima mencionados, sem que com isso se excluam outros olhares sobre os entendimentos e amplitudes das dimensões dentro da presente organização.

Pode-se observar que nas Tabelas 3 e 4 são descritas, na primeira coluna, as 25 cartas sorte e revés; na segunda coluna, suas articulações com as três dimensões do DS e do DI; e, na terceira coluna,

TABELA 1 - Dimensões e critérios do desenvolvimento sustentável.

\begin{tabular}{lll}
\hline \multicolumn{1}{c}{ Dimensão ambiental* } & \multicolumn{1}{c}{ Dimensão econômica** } & \multicolumn{1}{c}{ Dimensão social*** } \\
\hline - Proteção ambiental: das fontes & - Resultado econômico: incentivo às & - Envolvimento com a comunidade \\
bióticas e abióticas & práticas ambientalmente corretas que & - Postura ética \\
- Ecoeficiência & produzam renda & - Respeito aos direitos humanos e do \\
- Gestão de resíduos & & trabalhador \\
\hline
\end{tabular}

* Envolve a integridade do meio ambiente, o cuidado.

** Envolve a vitalidade da economia, sua prosperidade.

*** Envolve a equidade para a sociedade, a dignidade humana.

FONTE: Elaborada pelos autores.

TABELA 2 - Dimensões e critérios do desenvolvimento insustentável.

\begin{tabular}{lll}
\hline \multicolumn{1}{c}{ Dimensão ambiental* } & \multicolumn{1}{c}{ Dimensão econômica** } & \multicolumn{1}{c}{ Dimensão social*** } \\
\hline - Ausência de proteção ambiental: das & - Resultado econômico: sem incentivo & - Ausência de envolvimento com a \\
fontes bióticas e abióticas & às práticas ambientalmente corretas que & comunidade \\
- Sem preocupação com ecoeficiência & produzam renda & - Ausência de postura ética \\
- Sem práticas de gestão de resíduos & & - Desrespeito aos direitos humanos e do \\
& & trabalhador \\
\hline
\end{tabular}

* Envolve a não integridade do meio ambiente, falta de cuidado.

** Envolve prejuízos à vitalidade da economia e sua prosperidade.

*** Envolve a não equidade para a sociedade e atendimento à dignidade humana.

FONTE: Elaborada pelos autores. 
TABELA 3 - Panorama das dimensões do desenvolvimento sustentável contidas nas cartas sorte do jogo Banco Imobiliário Sustentável.

\begin{tabular}{lcl}
\hline \multicolumn{1}{c}{ Descrição das cartas sorte } & Dimensão do DS & \multicolumn{1}{c}{ Análise } \\
\hline $\begin{array}{l}1-\text { "Sua empresa desenvolveu um programa } \\
\text { de voluntariado para seus funcionários e a } \\
\text { produtividade aumentou" }\end{array}$ & Social & $\begin{array}{l}\text { A dimensão social está contida nessa carta devido } \\
\text { ao envolvimento com a comunidade apresentado na } \\
\text { descrição. }\end{array}$ \\
\hline $\begin{array}{l}2-\text { "Você abriu uma ONG de proteção } \\
\text { ambiental [...]" }\end{array}$ & Ambiental & $\begin{array}{l}\text { A dimensão ambiental se ajusta a essa carta, uma vez } \\
\text { que o papel das ONGs envolve proteção da natureza, } \\
\text { seu cuidado por meio da educação ambiental. }\end{array}$ \\
\hline $\begin{array}{l}3-\text { "Suas empresas reciclam papel, plástico } \\
\text { e alumínio" }\end{array}$ & $\begin{array}{l}\text { Ambiental e } \\
\text { econômica }\end{array}$ & $\begin{array}{l}\text { As duas dimensões inserem-se nessa carta, pois } \\
\text { ocorre maior aproveitamento dos resíduos, gestão e } \\
\text { produção de renda ambientalmente corretos, a partir } \\
\text { de seu reaproveitamento. }\end{array}$ \\
\hline $\begin{array}{l}\text { As duas dimensões inserem-se nessa carta, pois } \\
\text { um sucesso" }\end{array}$ & $\begin{array}{l}\text { Ambiental e } \\
\text { ocorre o cuidado com o solo e os recursos hídricos } \\
\text { na plantação dos orgânicos e geração de renda de } \\
\text { maneira ambientalmente correta. }\end{array}$ \\
\hline
\end{tabular}

5 - "Sua empresa recebeu um prêmio por ser Social, ambiental e Nessa carta é possível contemplar as três dimensões, ecologicamente responsável" econômica pois ser ecologicamente correto envolve uma economia com vitalidade, um envolvimento com a sociedade e integridade do ambiente natural.

6 - "Você decidiu instalar um painel solar na Ambiental e Essa carta insere-se nas duas dimensões, pois auxilia sua casa e economizou com energia elétrica" econômica na redução da demanda de energia de fontes não renováveis e é uma prática ambientalmente correta.

7-"Você ajudou causas sócias - e economizou Social um bom dinheiro em impostos"

Essa carta pertence à dimensão social, uma vez que apresenta envolvimento e postura ética com a comunidade.

8 - "Seu livro sobre a vida sustentável será Social publicado por uma grande editora"

Nessa carta é possível perceber o envolvimento e o compartilhamento das informações com a sociedade sobre outro modelo de vida.

9 - "Você inventou um novo modelo de carro elétrico"

Ambiental e

Por mais que não ocorra a especificação da fonte econômica geradora de energia elétrica para o funcionamento do carro elétrico, as duas dimensões podem ser evidenciadas nessa carta, pois uma fonte solar reduz os impactos nos recursos naturais e produz renda de maneira menos agressiva para o meio ambiente.

\begin{tabular}{llll}
\hline $\begin{array}{l}10 \text { - "A usina de reciclagem energética que } \\
\text { você financiou reduziu os gastos da sua } \\
\text { empresa com energia" }\end{array}$ & $\begin{array}{l}\text { Ambiental e } \\
\text { econômica }\end{array}$ & $\begin{array}{l}\text { As duas dimensões justificam-se pelo } \\
\text { reaproveitamento e ecoeficiência dos resíduos e por } \\
\text { ser essa uma atividade ambientalmente correta. }\end{array}$ \\
\hline $\begin{array}{l}11 \text { - "Você trocou seu carro por uma bicicleta } \\
\text { - e economizou na gasolina" }\end{array}$ & $\begin{array}{l}\text { Ambiental e } \\
\text { econômica }\end{array}$ & $\begin{array}{l}\text { Trocar um carro por uma bicicleta implica não } \\
\text { utilização de fontes não renováveis de maneira } \\
\text { excessiva e incentivo a práticas que reduzam a } \\
\text { poluição do ar e do mercado ecológico. }\end{array}$ \\
\hline 12 - "Você protegeu suas terras do & $\begin{array}{l}\text { Ambiental e } \\
\text { econômica }\end{array}$ & $\begin{array}{l}\text { Essa carta situa essas duas dimensões, pois protege } \\
\text { o ambiente natural e produz renda de maneira } \\
\text { ambientalmente correta. }\end{array}$ \\
$\begin{array}{l}\text { desmatamento e agora está faturando uma } \\
\text { nota com o turismo ecológico" }\end{array}$
\end{tabular}

FONTE: Elaborada pelos autores. No jogo original são utilizadas 32 cartas sorte e revés. No entanto, para este artigo, foram utilizadas 25 , pois sete delas não apresentavam ligação com a discussão. 
TABELA 4 - Panorama das dimensões do desenvolvimento insustentável contidas nas cartas revés do jogo Banco Imobiliário Sustentável.

\begin{tabular}{lcl}
\hline \multicolumn{1}{c}{ Descrição das cartas revés } & Dimensão do DI* & \multicolumn{1}{c}{ Análise } \\
\hline $\begin{array}{l}13 \text { - "Cancelou o projeto de Responsabilidade } \\
\text { Social de sua empresa por ele gerar altos custos, } \\
\text { porém isso não agradou a ninguém" }\end{array}$ & Social & $\begin{array}{l}\text { A dimensão social justifica-se pelo rompimento do papel } \\
\text { social da empresa com a sociedade. }\end{array}$ \\
$\begin{array}{l}14 \text { - "Você foi para a praia e deixou todo o lixo } \\
\text { na areia" }\end{array}$ & Ambiental e social & $\begin{array}{l}\text { As duas dimensões se justificam pela não gestão dos resíduos, } \\
\text { prejudicando a fauna e a flora, além do ser humano, uma vez } \\
\text { que outras pessoas circulam por esse local; é antiético. }\end{array}$ \\
\hline $\begin{array}{l}15 \text { - "O rio da sua cidade está poluído - e a } \\
\text { culpa é sua" }\end{array}$ & Ambiental e social & $\begin{array}{l}\text { A poluição do rio implica a postura antiética da população } \\
\text { e a destruição do recurso hídrico e de suas ligações com os } \\
\text { demais ecossistemas. }\end{array}$ \\
\hline $\begin{array}{l}16 \text { - "Você demitiu um funcionário sem justa } \\
\text { causa e perdeu a ação na Justiça" }\end{array}$ & Social & $\begin{array}{l}\text { Essa carta contempla a dimensão social, pois evidencia o não } \\
\text { respeito aos direitos humanos e do trabalhador e uma postura } \\
\text { antiética da empresa para com o funcionário. }\end{array}$ \\
\hline
\end{tabular}

17 - "Você não estava satisfeito com seus oito Social, ambiental e Essa ação representa um não envolvimento na busca pela carros importados e decidiu comprar mais um" econômica equidade na sociedade, além de não incentivar práticas ambientalmente corretas e não proteger o meio ambiente.

18 - "O petróleo está em alta, e você tem jatinho, Social, ambiental e Com a redução do recurso, ocorre o desequilíbrio em sua iate, limusine...." econômica distribuição, o que afeta a sociedade, o meio ambiente e a economia.

19 - "Suas empresas não usam embalagens recicláveis - e as vendas estão caindo"

20 - "Você não instalou filtros de ar em suas Social fábricas"

21 - "O agrotóxico que você usou destruiu toda Social, ambiental e a plantação" econômica

22 - "Suas empresas desperdiçam água e energia elétrica"

Ambiental e econômica

23 - "Você decidiu fechar a sua fábrica de produtos químicos"
Ambiental e A prática envolve a não gestão de seus recursos e ecoeficiência econômica deles, além de não incentivar práticas ambientalmente corretas.

A não instalação de filtros de ar afeta diretamente a saúde dos funcionários, o que evidencia um não envolvimento e não respeito pelos trabalhadores.

Essa consequência afeta a população que vive próxima da área pela possibilidade de contaminação da água e do solo, o que afeta a vida do ecossistema e prejudica a economia rural, pois demandará novo investimento e recuperação da plantação e do solo.

Desperdiçar energia e água afeta o meio ambiente, pois demanda maior extração e manutenção da atividade, o que atinge a economia e a prosperidade da empresa.

Acredita-se que nessa carta não seja possível inserir as dimensões do DS e do DI, pois fechar uma fábrica de produtos químicos pode ser positivo para o meio ambiente, uma vez que ela provoca o lançamento de inúmeros compostos na água, no solo e no ar, e pode também ser negativo pela redução de empregos e por prejudicar a economia. Assim, essa carta não se insere nos critérios estabelecidos para a avaliação, pois, como carta revés, ela é entendida como uma ação negativa.

24 - "Foi multado por jogar lixo pela janela do Social e ambiental Essa prática implica prejudicar a conservação e a proteção carro" ambientais, além de influenciar a própria vida do ser humano.

25 - "Sua empresa foi multada por poluir Social, ambiental e Nessa carta, as três dimensões podem ser contempladas, pois demais" econômica a poluição afeta a saúde humana e do ecossistema, além de ser uma ação que não incentiva uma prática ambientalmente correta.

\footnotetext{
* Desenvolvimento insustentável.

FONTE: Elaborada pelos autores.
} 
suas respectivas análises, o que justifica a articulação de cada carta sorte e revés com suas dimensões. Das 25 cartas avaliadas, 24 foram inseridas nas dimensões. Não foi possível agrupar apenas uma, por ela não ter sido compreendida. As dimensões mais contempladas pelo jogo foram: dimensão social, com seis cartas; dimensão ambiental, uma carta; social e ambiental, com três cartas; ambiental e econômica, com nove cartas; e social, ambiental e econômica, com cinco cartas.

Por se tratar de um jogo com enfoque nas questões ambientais e econômicas, observa-se que essas dimensões aparecem com maior frequência conjuntamente, sem ao mesmo tempo se esquecer da dimensão social, uma vez que está atrelada às outras duas dimensões. As dimensões apresentam diversos diálogos e interseções, o que acaba enriquecendo suas discussões. Para Dias (2015, p. 45),

um ambiente sustentável é aquele em que os recursos da Terra são capazes de sustentar a vida dos ecossistemas, a saúde e o progresso aceitável de forma renovável. Uma economia sustentável ocorre quando as decisões de desenvolvimento, políticas e práticas das pessoas não esgotam os recursos da Terra. Uma sociedade sustentável é caracterizada por pessoas que vivem em harmonia com a natureza e umas com as outras em nível mundial.

Um equilibrado desenvolvimento sustentável poderá alcançar a manutenção e a harmonia da vida na Terra. Porém, o equilíbrio do DS passa anteriormente pela alteração do atual modelo de desenvolvimento, o capitalismo industrial. Afinal, "[...] o capitalismo é a primeira sociedade capaz de uma verdadeira catástrofe ambiental planetária, tal que pode mesmo colocar em risco os requisitos materiais para a sua existência” (Burkett, 1999, p. 68 apud Aguiar \& Bastos, 2012, p. 91).
Ressalta-se que o capitalismo não é um modo de produção fora da natureza (Aguiar \& Bastos, 2012). Sendo assim, possui tendências particulares no que tange à relação entre sociedade e meio ambiente, conforme delimita Foladori (1999, p. 35):

\begin{abstract}
a tendência exclusiva mais geral é a produção ilimitada. [...] Mas esta tendência ilimitada à produção não é uma consequência natural da espécie humana, mas sim particular da produção capitalista. [...] A tendência exclusiva mais grave do capitalismo é a geração de população excedente. [...] Não tem existido organização econômica na história da humanidade que gere população excedente como algo "natural" e necessário.
\end{abstract}

A adoção de um modelo baseado no capitalismo natural, conforme apresentado na seção anterior, poderá auxiliar na melhoria de vida da população e na sobrevida do ambiente natural. Nessa linha de pensamento, Cenci \& Burmann (2013, p. 143) afirmam que "é urgente a renovação da sociedade de consumo por outra que introduza critérios de vida coletiva, em substituição à corrente individualista dominante. A natureza carece de ações humanas que [...] a valorizem e respeitem suas formas de regeneração".

No jogo Banco Imobiliário Sustentável, é possível identificar a emersão do capitalismo natural (critérios: produtividade radical dos recursos, biomimetismo, economia de serviço e de fluxo e investimento no capital natural - esses critérios foram apresentados na seção 4) nas cartas sorte e revés que apresentam as seguintes descrições:

Cartas sorte: "Suas empresas reciclam papel, plástico e alumínio"; "Você decidiu instalar um painel solar na sua casa e economizou com energia elétrica"; "Você inventou um novo modelo de carro elétrico"; "A usina de reciclagem energética que você financiou reduziu os gastos da sua empresa 
com energia"; "Você protegeu suas terras do desmatamento e agora está faturando uma nota com o turismo ecológico"; e "Você trocou seu carro por uma bicicleta - e economizou na gasolina";

Cartas revés: "Você não estava satisfeito com seus oito carros importados e decidiu comprar mais um"; "Suas empresas não usam embalagens recicláveis - e as vendas estão caindo"; "O agrotóxico que você usou destruiu toda a plantação"; "Você foi para a praia e deixou todo o lixo na areia"; "Suas empresas desperdiçam água e energia elétrica"; "Foi multado por jogar lixo pela janela do carro"; e "Sua empresa foi multada por poluir demais".

No entanto, por mais que o capitalismo natural seja evidente, o pano de fundo do jogo é o capitalismo industrial, aquele que objetiva vencer, deter o poder sobre os outros, comandar os rumos da economia e influenciar a estrutura social e econômica do planeta. "Parece que estamos enfrentando dificuldades enormes para conseguir construir sociedades viáveis, do ponto de vista do acesso igualitário às riquezas materiais e simbólicas e do desenvolvimento qualitativo e sustentável" (Orofino, 2013, p. 113-114).

A meta de se tornar o jogador com o maior número de certificados de carbono revela o não atendimento a uma sociedade equitativa, e sua linguagem incentiva seu público, as crianças, a buscar sempre a melhor posição, a maior quantia, questões que não deveriam mais estar sendo instigadas no momento em que a sociedade humana enfrenta uma crise civilizatória. Conforme Murray (2003, p. 141 apud Ferreira \& Pedrini, 2015, p. 3),

os jogos também podem ser vistos como textos que proporcionam interpretações de experiências. Por exemplo, o jogo de tabuleiro Banco Imobiliário (Monopoly) pode ser visto como uma interpretação do capitalismo, uma encenação dos encantos e decepções de uma economia cuja soma total é sempre zero, na qual para enriquecer é preciso empobrecer os outros. Ou pode ser visto como uma expressão padronizada de nosso conhecimento de que sucesso na vida é sempre resultado tanto de planejamento quanto da sorte. Quando jogamos Banco Imobiliário, estamos fazendo parte de um drama estruturado que proporciona, além de seu final ganhar/perder, momentos nos quais manifestamos nossa ambição, ganância e benevolência, e nossas tendências para correr riscos e explorar os outros.

Dessa forma, pensar em uma educação para a sustentabilidade no jogo se torna insustentável, pois é necessária uma transformação na cultura do capitalismo industrial que incentiva a competição para uma cultura de cooperação, baseada na construção de valores sociais equitativos e relações de equilíbrio entre o meio econômico e o ambiental, conforme destaca a UNESCO (1999, p. 50):

\begin{abstract}
a educação em prol do desenvolvimento sustentável requer um enfoque equilibrado, em que se evite insistir na modificação dos estilos individuais de vida. Deve-se reconhecer que muitos dos problemas mundiais, inclusive os problemas ambientais, relacionam-se com nossa maneira de viver e que, para solucioná-los, é necessário transformar as condições sociais da vida humana, assim como alguns estilos de vida individuais.
\end{abstract}

O jogo pode ser pensado como um recurso educativo ou como uma estratégia pedagógica, pois, aliada à interação e à mediação, é possível pensar em uma ressignificação das peças e das problematizações contidas em seu circuito. O jogo Banco Imobiliário Sustentável apresenta-se com um campo fértil e problematizador para o processo de ensino-aprendizagem de questões ligadas à educação ambiental, como a perspectiva da sustentabilidade e a construção de valores no que diz respeito ao relacionamento entre ser humano e natureza (Ruscheinsky, 2003). 
Os destinatários do jogo são as crianças a partir de seis anos de idade, mas ele pode ser utilizado também por adolescentes e adultos. No jogo, o maior desafio a ser enfrentado por essas crianças é refletir sobre o mundo que ali está posto e como torná-lo melhor. Como tornar essa experiência fictícia, que Elkonin (2009) chama de protótipo da futura atividade séria, em algo concreto e positivo, sem considerar a permanência do capitalismo industrial, que fragmenta e provoca tantos impactos na sociedade e no ambiente natural? "Por não considerar os limites orgânicos da natureza, o capitalismo intensifica a demanda por mais capital para manter o mesmo nível de lucratividade mediante o declínio das suas condições de produção" (Quintana \& Hacon, 2011, p. 438).

Diante dos resultados alcançados, a percepção de infância no jogo Banco Imobiliário Sustentável é aquela apresentada por Postman (1999), uma infância que está desaparecendo, pois o universo dos negócios, do capitalismo e da ambição pertence ao mundo adulto. A ideia contida no jogo é que isso também pode ser realizado pelas crianças, uma vez que a faixa etária de sua utilização é de seis anos.

Postman (1999) reforça essa ideia ao afirmar que, com o advento das tecnologias, as informações passaram a atingir todas as pessoas, sem diferenças entre grupos etários, de desenvolvimento, e que houve uma homogeneização da informação. A linguagem utilizada entre os grupos tornou-se a mesma, o que é possível identificar no jogo: uma linguagem do universo dos negócios inserida no universo infantil pelo interesse econômico, promovido pelas mídias e seus produtos culturais.

O mundo do conhecido e do ainda não conhecido está ligado pela ponte do espanto. Mas o espanto acontece em grande parte numa situação em que o mundo da criança está separado do mundo do adulto, onde as crianças devem procurar entrar mediante suas perguntas. Como a mídia funde os dois mundos, como a tensão criada pelos segredos a serem desvendados diminui, o cálculo do espanto muda. A curiosidade é substituída pelo cinismo, ou pior ainda, pela arrogância. Restam-nos, então, crianças que confiam, não na autoridade do adulto, mas em notícias vindas de parte nenhuma. Restam-nos crianças que recebam respostas a perguntas que nunca fizeram. Em resumo, não nos resta mais nenhuma criança (Postman, 1999, p. 104).

O surto capitalista incentivou o desenvolvimento tecnológico, que, por sua vez, desestabilizou a sociedade global, tornando-a refém do próprio sistema. A infância no capitalismo se tornou mais um momento de exploração e investimento, o que pode ser percebido no jogo Banco Imobiliário Sustentável e nos demais jogos, pois esses envolvem a mídia em sua estrutura e investem em uma linguagem que convença as crianças e as atraia para o mundo não real. "Há uma crescente 'descartabilidade' de produtos e também de personagens e celebridades, reais e fictícias. É a ideologia da vida curta. Muito mais do que memória social, nossa cultura contemporânea produz também um acelerado processo de esquecimento" (Orofino, 2013, p. 116).

A distância entre o mundo real e o imaginário é o equilíbrio necessário na utilização de jogos, mesmo que inicialmente eles sejam uma escola para aperfeiçoar a linguagem, favorecendo a comunicação e a interação.

\section{Conclusão}

Ao longo deste artigo, tentou-se estruturar um percurso que atendesse à questão teórica e que pudesse responder ao objetivo proposto, além das questões norteadoras. Com isso, pode-se afirmar que o jogo Banco Imobiliário Sustentável contempla as três dimensões do desenvolvimento sustentável, demonstrando uma inclinação para 
as dimensões ambientais e econômicas, sem, ao mesmo tempo, deixar de atender à dimensão social. As interseções criadas pelo jogo valorizam as discussões educacionais em relação às dimensões do desenvolvimento sustentável, pois demandam um olhar sobre as três perspectivas, isto é, um olhar que promova a compreensão da complexidade que envolve a vida na Terra.

O jogo segue a linha do capitalismo natural, sem esquecer que sua base é o capitalismo industrial. A crítica sobre o jogo situa-se nessa avaliação, pois um jogo que preza pela consciência ambiental não pode ser essencialmente competitivo. A busca pela conscientização da população e, principalmente, das crianças permeia uma cultura de cooperação, de apoio mútuo e equilíbrio, o que não ocorre na proposta do jogo. O valor de cooperação, nesse sentido, não existe no jogo.

Ainda dentro dessa perspectiva, a educação para a sustentabilidade está embasada em princípios de equidade e harmonia entre todos os setores, sejam eles culturais, políticos, econômicos, sociais e ambientais. Acredita-se que o jogo ofereça uma primeira reflexão sobre as discussões que o desenvolvimento sustentável envolve, ampliando o conhecimento dos participantes para questões ainda não visíveis ou não contextualizadas. Porém, o jogo ainda não possui uma estrutura que permita pensar em uma educação para a sustentabilidade. Seria necessário modificar as suas bases, transformado-o em cooperativo e de caráter equitativo.

Para o campo da educação, o jogo funciona como um motor para o processo de ensino-aprendizagem, pois, dependendo da maneira como for utilizado e de quem mediar o processo, desperta curiosidade e inquietações sobre algumas abordagens. Mesmo não atendendo a todos os critérios de uma educação para a sustentabilidade, o jogo possui potencial educativo, desde que haja uma presença mediadora para o diálogo e a crítica, superando a característica do lúdico por si mesmo e atuando como gatilho para discussões e construções de conhecimento. A restrição educativa está no caráter competitivo, o que não impede sua modificação e readaptação.

A inserção de jogos educativos e, principalmente, da ludicidade ambiental na infância mostra-se fundamental para o momento atual, pois a infância possibilita a formação das primeiras experiências, dos comportamentos iniciais e da base para o futuro adulto. Assim, a linguagem contida no jogo possibilita identificar os caminhos positivos e negativos percorridos pelo capitalismo e como a infância é "engolida" por esse sistema.

Leff (1998, p. 213) afirma que as estratégias educativas para o desenvolvimento sustentável e, consequentemente, para a sustentabilidade passam pela

necessidad de revaluar y actualizar lós programas de educación ambiental, al tiempo que se renuevan sus contenidos com base em los avances del saber y la democracia ambiental. La educación para el dedesarrollo sustentable demanda así nuevas orientaciones y contenidos; nuevas prácticas pedagógicas donde se plasmen lãs relaciones de produción de conocimientos y lós procesos de circulación, transmisión y diseminación del saber ambiental.

O jogo possui uma linguagem que ganha força no momento atual, em que a sociedade global busca alternativas para conciliar a economia com a natureza, ou seja, um futuro possível, com possibilidade de atender às demandas humanas e manter o equilíbrio do sistema ecológico. A insustentabilidade contida no jogo revela um caminho que não deve ser percorrido, e sim combatido.

A percepção de infância nesse produto cultural destinado ao público infantil é a de uma infância 
em desaparecimento, conforme destacado anteriormente, pois o mundo dos negócios é do mundo adulto. Comprar, alugar e vender não são ações do público infantil, mas informações que circulam por outras etapas, e não necessárias àquelas da vida. As discussões ambientais, sim, podem e devem permear a infância, de acordo com os níveis de desenvolvimento de cada indivíduo. No entanto, elas somente serão produtivas quando houver professores informados e capacitados atuando como mediadores do processo de ensino.

Assim, espera-se que as posturas e os comportamentos desse público infantil destinatário do jogo ultrapassem a barreira do capitalismo industrial e

\section{Referências}

Aguiar, J. V.; Bastos, N. Uma reflexão teórica sobre as relações entre natureza e capitalismo. Revista Katálysis, 15(1), 84-94, 2012. Disponível em: <https:// periodicos.ufsc.br/index.php/katalysis/article/view/S141449802012000100010/22056>.

Andrade, D. C.; Romeiro, A. R.; Simões, M. S. From an empty to a full world: a nova natureza da escassez e suas implicações. Economia e Sociedade, 21(3), 695-722, 2012. Disponível em: $<$ http://www.scielo.br/pdf/ecos/v21n3/09. pdf $>$.

Braskem. Perfil. 2015. Disponível em: <https://www. braskem.com.br/perfil >. Acesso em: 07 dez. 2015.

Cenci, D. R.; Burmann, T. K. Direitos humanos, sustentabilidade ambiental, consumo e cidadania. Revista Direitos Humanos e Democracia, 1(2), 131-157, 2013. Disponível em: <https://www.revistas.unijui.edu.br/index.php/direitoshumanosedemocracia/article/viewFile/338/2460>.

CMMAD - Comissão Mundial sobre o Meio Ambiente e Desenvolvimento. Nosso futuro comum. 2. ed. Rio de Janeiro: Fundação Getúlio Vargas, 1991.

Dias, R. Sustentabilidade: origem e fundamentos; educação e governança global; modelo de desenvolvimento. São assumam como cultura um capitalismo natural, da cooperação e da busca pelo equilíbrio socioambiental. Porém, sabe-se que o caminho a ser percorrido é complexo, envolve uma reconstrução cultural, um querer mudar, pois de nada adianta trabalhar com a educação infantil, ou em qualquer outro nível de ensino, se, a partir do momento em que a escola se transforma no palco real, no dia a dia, as barreiras continuarem as mesmas e não houver espaço para esse novo modelo de cultura. Portanto, a educação, como um processo de formação humana, necessita reaprender e reensinar o ser humano a viver na época por ele criada, o Antropoceno.

Paulo: Atlas, 2015. Disponível em: $<$ www.ucs.br $>$. Acesso em: 08 dez. 2015.

Elkonin, D. B. Psicologia do jogo. Tradução de Álvaro Cabral. 2. ed. São Paulo: WMF Martins Fontes, 2009. (Coleção: Textos de Psicologia).

Estrela. História. 2015. Disponível em: <http://www. estrela.com.br/sobre-a-estrela/historia/>. Acesso em: 07 dez. 2015.

Fernández, A. O saber em jogo: a psicopedagogia propiciando autorias de pensamento. Tradução de Neusa Kern Hickel. Porto Alegre: Artmed, 2001.

Ferran, P.; Mariet, F.; Porcher, L. Na escola do jogo. Tradução de Maria de Assunção Santos. Lisboa: Estampa, 1979. (Coleções: Técnicas de educação).

Ferreira, J. C. B.; Pedrini, I. A. D. As ideias neoliberais aplicadas ao espaço lúdico: um estudo da propaganda no jogo Banco Imobiliário Sustentável. In: Anais do Congresso de Ciências da Comunicação na Região Centro-Oeste, 17., 2015, Campo Grande. Mato Grosso do Sul: Intercom, 2015. p. 1-13. Disponível em: <http://www.portalintercom.org.br/ anais/centrooeste2015/resumos/R46-0398-1.pdf $>$. Acesso em: 27 dez. 2015. 
Fleury, M-F.; Somain,. O Banco Imobiliário, um jogo geográfico. Confins: Revista Franco-Brasileira de Geografia, 5, 2009. Disponível em: <https://confins.revues.org/5601>.

Foladori, G. O Capitalismo e a crise ambiental. Raízes: Revista de Ciências Sociais e Econômicas, 19, 31-36, 1999. Disponível em: <http://www.ufcg.edu.br/ raizes/artigos/ Artigo_42.pdf $>$.

Freire, P. Educação e mudança. Tradução de Moacir Gadotti e Lilian Lopes Martin. 4. ed. Rio de Janeiro: Paz e Terra, 1981. (Coleção Educação e Mudança, v. 1).

Hawken, P.; Lovins, A.; Lovins, L. H. Capitalismo natural: criando a próxima revolução industrial. Tradução de Luiz A. de Araújo e Maria Luiza Felizardo. 6. reimp. São Paulo: Cultrix, 2007.

Huizinga, J. Homo ludens: o jogo como elemento da cultura. Tradução de João Paulo Monteiro. 4. ed. São Paulo: Perspectiva, 2000. (Coleção Estudos. Filosofia). Disponível em: <http://jnsilva.ludicum.org/Huizinga_HomoLudens. pdf $>$. Acesso em: 10 mar. 2015.

Jacobi, P. Meio ambiente e sustentabilidade. In: CEPAM, Fundação Prefeito Faria Lima. O município no século XXI: cenários e perspectivas. Edição especial. São Paulo: Cepam, 1999. Cap. 4. p. 175-183.

Leff, E. Saber ambiental: sustentabilidad, racionalidad, complejidad, poder. México: Siglo XXI Editores/Pnuma, 1998.

Leff, E. Epistemologia ambiental. Tradução de Sandra Valenzuela. 5. ed. São Paulo: Cortez, 2010.

Leif, J.; Brunelle, L. O jogo pelo jogo: a atividade lúdica na educação de crianças e adolescentes. Tradução de Júlio César Castañan Guimarães. Rio de Janeiro: Zahar Editores, 1978. (Ciência da Educação).

Lemos, I. Pedagogia do consumo: família, mídia e educação. Belo Horizonte: Autêntica, 2007.

Loureiro, C. F. B. Sustentabilidade e educação: um olhar da ecologia política. São Paulo: Cortez, 2012. (Coleção Questões da Nossa Época, v. 39).
Orofino, M. I. Ciranda de sentidos: crianças, consumo cultural e mediações. In: Fantin, M.; Girardello, G. Liga, roda, clica: estudos em mídia, cultura e infância. Campinas: Papirus, 2013. Cap. 7. p. 113-126. (Coleção Ágere).

Postman, N. O desaparecimento da infância. Rio de Janeiro: Graphia, 1999.

Quintana, A. C.; Hacon, V. O desenvolvimento do capitalismo e a crise ambiental. O Social em Questão, 25/26(14), 427-444, 2011. Disponível em: <http://osocialemquestao. ser.puc-rio.br/media/21_OSQ_25_26_Quintana_e_Hacon. pdf $>$.

Ruscheinsky, A. No conflito das interpretações: o enredo da sustentabilidade. Revista Eletrônica do Mestrado em Educação Ambiental, 10, 39-50, 2003.

UNESCO. Educação para um futuro sustentável: uma visão transdisciplinar para ações compartilhadas. Brasília: IBAMA, 1999. Conferência Internacional sobre Meio Ambiente e Sociedade: educação e conscientização pública para a sustentabilidade. Disponível em: $<$ http://unesdoc. unesco.org/images/0011/001106/110686porb.pdf>. Acesso em: 07 dez. 2015.

UNESCO. Década da Educação das Nações Unidas para um Desenvolvimento Sustentável: 2005-2014. Brasília: UNESCO, 2005. Disponível em: <http://unesdoc.unesco. org/images/0013/001399/139937por.pdf>. Acesso em: 07 dez. 2015.

Vigotski, L. S. Psicologia pedagógica. Tradução de Claudia Schilling. Porto Alegre: Artmed, 2003. (Edição comentada).

Vigotski, L. S. A formação social da mente: o desenvolvimento dos processos psicológicos superiores. 7. ed. Tradução de José Cipolla Neto, Luís Silveira Menna Barreto e Solange Castro Afeche. São Paulo: Martins Fontes, 2007.

Volpato, G. Jogo, brincadeira e brinquedo: usos e significados no contexto escolar e familiar. Florianópolis: Cidade Futura, 2002.

Wikipédia. Monopoly. 2015. Disponível em: <https:// pt.wikipedia.org/wiki/Monopoly>. Acesso em: $07 \mathrm{dez}$. 2015. 